\title{
Introduction of Gender Identity through Role-playing Activities in Early Childhood
}

\author{
Lathipah Hasanah ${ }^{1, *}$, Mohamad Syarif Sumantri ${ }^{1}$, Nurbiana Dhieni ${ }^{1}$, Nopiana ${ }^{2}$ \\ ${ }^{1}$ Postgraduate Program, Universitas Negeri Jakarta, 13220, DKI Jakarta, Indonesia \\ ${ }^{2}$ Faculty of Teacher Training and Education, Universitas Lampung, 35141, Lampung, Indonesia
}

Received July 29, 2020; Revised November 1, 2020; Accepted November 11, 2020

\begin{abstract}
Cite This Paper in the following Citation Styles
(a): [1] Lathipah Hasanah, Mohamad Syarif Sumantri, Nurbiana Dhieni, Nopiana, "Introduction of Gender Identity through Role-playing Activities in Early Childhood," Universal Journal of Educational Research, Vol. 8, No. 12A, pp. 7296 - 7304, 2020. DOI: 10.13189/ujer.2020.082512.
\end{abstract}

(b): Lathipah Hasanah, Mohamad Syarif Sumantri, Nurbiana Dhieni, Nopiana (2020). Introduction of Gender Identity through Role-playing Activities in Early Childhood. Universal Journal of Educational Research, 8(12A), 7296 - 7304. DOI: 10.13189/ujer.2020.082512.

Copyright $\odot 2020$ by authors, all rights reserved. Authors agree that this article remains permanently open access under the terms of the Creative Commons Attribution License 4.0 International License

\begin{abstract}
The objective of the research is to explain the process and learning outcomes in utilizing role play which can improve gender identity in play group, Bekasi with child research subject amounting of 15 people. The data analysis technique used in this research was a qualitative and quantitative analysis. Qualitative analysis was conducted on data collected through field note, observer sheet action, interview note, and documentation record. Analysis of quantitative data used a calculation of how much percentage increase gender identity after the action through using role playing activities. The implementation process of learning using role playing activities both of teacher and children showed an increase. In the first cycle of learning with a teacher, it had undertaken the percentage rate which reached $50.7 \%$ and $81.8 \%$ in the second cycle. Based on the quantitative research data, the qualitative research data showed that learning using role playing activities might improve introduction of gender identity aged 3-4 years old. The implication of this research is, process for early childhood learning, especially introduction of gender identity should use the role-playing activities, giving motivation, giving stimulation, giving example, and giving problems.
\end{abstract}

Keywords Gender Identity, Role-playing, Early Childhood

\section{Introduction}

Gender recognition needs to be conducted so that children understand the different roles between men and women. Through gender recognition, parents can provide an understanding to children about personal areas of their body that should not be seen by others. Gender recognition is not implemented in children in the school environment but also in the home environment. Parents are role models for children, figures and personalities that children will emulate. Arends explained that boys and girls learn to be male and female not only in school but also see what their families do [1]. Furthermore, early gender recognition is closely related to the development and formation of behavior patterns and personality of children in adulthood [2].

Therefore, all types of information that is true and closely related to gender identity must be applied appropriately so that it can be stored in a child's memory in the long run. With the advances in technology and communication, information about the world is very easily accessible especially by children. Television media as the media which are the most widely owned by the public are the simplest to access often display gender bias. It has been shown on one private television station that displays ranging from the host to the transgender guest star. 
Several previous studies related to gender identity were conducted by Roig and Hutardo with the title "The digital gap: gender and computer games". This study states that computer games can introduce children to gender perceptions [3]. Gender-related research was also conducted by Nielsen with the title "Identity performance in role-playing games". This study explains role play in introducing children's self-identity [4]. Furthermore, research conducted by Liu entitled "Understanding player behavior in online games: The role of gender" understands player behavior in online games about gender roles.

Some previous research on gender identity is more looking for data on the influence of understanding gender identity in the lives of children. The methods and media used have not specifically aimed at developing children's understanding of their gender identity. Gender identity in question refers to the sensitivity of the children about himself as a man or woman which including the dimensions of knowledge, understanding, acceptance as a man or woman. This research had a focus to provide children an understanding of their gender identity through role-playing activities. Through role play, children can put various kinds of clothes on the characters in the paper. It is following the opinion of Woolfolk, at the age of 4 or 5 years, children should have developed a gender scheme describing clothes, games, toys, behavior, and careers which are right for boys and girls [5]. Hence, we need a game that can introduce children to their gender identity.

Based on the background description above, it is necessary to develop a role-playing activity to introduce gender identity to children, bearing in mind that the implementation of learning delivered to children must be concrete and oriented to the play activities. In this case, the author raised a topic following the conditions encountered today, which is: "Increasing Gender Identity in Children Aged 3-4 Years through Role Play Activities at KB Al-Ikhlas, Bekasi."

\section{Literature Review}

\subsection{Gender Identity}

Identity is a legal concept in the United Nation convention on children's rights. It is the right of every child from birth. Children must be registered immediately after birth, have a birth certificate, be given a name, the right to obtain nationality and the right to be cared for by their parents. It indicates that the birth certificate is the clearest proof of respect for the children's identity. Morrow argued that gender identity is how one's understanding and awareness of his own gender [6]. It means that from an early age, the children must know himself as a man or woman and act according to the gender.

In line with this, Santrock explained that gender identity involves one's gender sense, including knowledge, understanding, and acceptance of being male or female [7]. One aspect of gender identity involves knowing whether a girl or boy can be implemented by most children at the age of 2.5 years. Gender identity continues to form at the age of 3-4 years [8]. It is at this point that children can make assertions about their gender and tend to choose activities and toys valued according to their gender. Like dolls for women and toy cars for men. There are four stages of the gender development process according to Newman, which are: (1) Understanding of gender concepts, (2) Learning by children about gender role standards and stereotypes, (3) Identification of parents, and (4) Formation of gender preferences [9]. Gender stereotypes are general categories describing views and beliefs about men and women. Stereotypes are cultural assumptions working as expectations so that men and women display certain characteristics which are appropriate to their sexes.

Gender identity is also a collection of thoughts and feelings which a person has about a person's membership as a male or female. There are several concepts about gender identity including (1) feelings that a person is a unique member of the gender category (gender type), (2) pleasant with one's gender (satisfaction of gender), (3) pressure from parents and friends peers to adjust to gender stereotypes (feel the pressure to adjust), (4) feelings that a person's gender is higher than other genders (bias between groups) [10]. The process is by which a person classifies himself, the existence of confidence (physically, socially and culturally) as a man or woman. A healthy gender identity is a gender identity which is consistent with its biological identity. A healthy gender identity enables a person to believe himself as a man or woman according to his physical nature and can act or behave as she or he should.

When children understand their gender identity, they begin to develop self-identity, self-confidence starts to grow, and begin to form relationships through play and peer relationships contributing to their emotional, social and cognitive development [11]. Recently, children also begin to describe their internal life and build their identities. Gender differences are identified, in the choice of soccer players, drivers, athletes, and pilots, usually played by boys only. Meanwhile, the role of mothers, nurses, aunts, played by women. It implies that gender differences in roles and identity choices begin to emerge in the early stages of children's development [12]. Gender identity can be related to how the children family's social life, media effects, and parents are the children's role models.

Therefore, it can be described that gender identity refers to the sensitivity of the children about himself as a man or woman which includes the dimensions of knowledge, understanding, and acceptance as a man or woman.

\subsection{Development Stages of Gender Identity}

Research has identified several stages of a children 
gender development, consisting of [13]: (a) age of infants, at this stage, children observe gender from the appearance, activity, and behavior which adults do. Most parents' interactions with their babies are shaped by the children's sex, and ultimately, it shapes the children's understanding on gender; (b) Ages 18-24 Months, in this stage, toddlers usually begin to define gender using messages from various sources. Children begin to develop their sense of self. Children look for patterns in their homes and observe the type of care given. Gender is one way to understand the sense of belonging and feel able to grow and develop safely; (c) ages 3-4 Years, at this stage, children have begun to observe their gender identity marked by the existence of several differences between men and women. Children start to connect the concept of differences between girls and boys.

They form rules or expectations about how each gender behaves and looks; and (d) ages 5-6 Years, at this stage, children's thinking maybe rigid in many ways. For instance, children aged 5-6 years are very aware of the rules and pressure to obey them. They do it rigidly because they are not ready to think more deeply about the beliefs and values on which rules are based.

\subsection{Role-playing}

Role-playing is a play activity to bring the roles existing in the real world into a role performance in the classroom or meeting. In role-playing activities, the children play a character they idolize. McCaslin argued that role-playing is a free play activity in which children explore, imitate and act following the character they want [14]. Frequently, children pretend to imitate people's activities, imaginative roles, cartoons or fairy tales. Children in different stages present the real world in play activities like playing doctor games, police officers, banks, and so on.

Smilansky emphasized that role-playing activities are play activities implemented when children imitate the activities of people they have met in their daily lives [15]. This play activity can also be identified to play fantasy or play pretend. Play is tremendously essential for the development of a healthy child. During the involvement in playing interactions with friends and family, children's language, social skills, and problem-solving abilities can be developed.

Role-playing can be described as "a free game of very young children in exploring the universe, imitating the actions and characters of those around it [16]." It is what children do naturally and spontaneously without distractions; pretending that it is a basic human response, especially in early childhood. The urge to play is fundamental to human experience and important for educational drama which is constructivist, role play for young people offers opportunities and means to understand the world, and is a bridge between the world of children and the world of adults. The spirit of this magical game built by children is often ignored in public school environments. However, it is a place where children begin to develop their creative and imaginative potential.

Role-playing is also a significant thing of dramatic play. Role-playing is when children use materials, sounds and actions to imitate others during play [17]. When children first learn role-playing, they take on a familiar role such as a parent or doctor. Children use materials as props to support their actions when they play roles. For instance, using the cylinder block as a shot pretending to be a doctor. When they become close with others in his role, they may imitate the actions and verbalization of a grocery seller, waiter, or firefighter.

Role-playing is a problem-solving method in groups which allows children to explore human problems, respond spontaneously, and follow up with directed discussion [18]. Role-playing consists of a problem occurrence or situation involving two or more people in which several decisions must be made to resolve the problem. In playing the role, there is a "problem story" where the human situation contained in the story is in a dilemma, and there is no solution offered. The interaction of interpersonal (social) factors, cultural devices and individual factors as key to the development and learning of individuals [19]. Role-playing involves the interaction between the children and the environment in the learning process.

\subsection{Micro Role-playing}

Micro role-playing is children's role playing through a character represented by small objects, for instance a cage with animals and small figures. Meanwhile, playing macro roles, children play into figures using large tools in which children use to create and play roles. It is in accordance with what was expressed by Bowman \& Lieberoth seen from the type of role playing which is divided into two types: macro and micro role-playing [20].

Role playing is seen from the number of actors, which are macro-role playing which is a collaboration of more than two people, even more especially for kindergarten-aged children. Meanwhile, micro role-playing is the beginning of collaborative play which is implemented by only two people even alone [21]. Playing micro roles puts more emphasis on the children being the mastermind of the media being played.

In micro role-playing, children will hold and move something small to compose a story scene. On the other hand, in playing macro roles, the children play a real role and become a certain character. As with playing micro-roles, they use small object props, which is playing paper puppets with pictures of people or pictures of something, playing finger puppets, playing dress-up games, and playing other props. Micro role-playing is conducted when children hold or move small objects to compose a scene [22]. When children play micro-roles, they learn to connect and take the others' point of view. Micro 
role-playing is a role-playing activity using small play materials such as a doll house completed with furniture and puppets so that children can play it [23]. In playing this micro role, children learn to develop their imagination.

Through micro-role playing, children become the director or puppeteer, and the objects become the players, such as hand puppets, finger puppets, puppets, without a scenario. Smilansky explained that playing micro-roles is children playing using symbols, such as words, movements, and toys to represent the real world [24]. Micro role-playing is broad, imaginative, related to real and fictional life. In this study, the dress up learning media will be used by children as a means of playing micro roles in which the children match the attributes of women and men into the images of female and male characters.

\subsection{Steps for Micro Role-playing}

Micro role-playing activities are playing activities which use mini media as a model, but in this play activity, there are steps that need to be known so that they can run according to the expected goals. Nurani asserted that the steps for micro role-playing activities are as follows [25]: (1) a teacher gathers the children to be given directions and rules for playing, (2) the teacher talks about the tools utilized by the children to play, (3) the teacher provides directions before playing and attendance for the children and counts the number of children together, (4) the teacher gives assignments to the children before playing according to their groups so that they do not fight each other while playing. The children are given explanations of the play tools that have been provided, (5) the teacher has prepared the games to utilize before the children start playing, (6) the children play according to their roles, (7) the teacher only supervises, accompanies the children in playing if needed, they help him, the teacher does not talk and does not help the children much, (8) after playing time is almost up, the teacher prepare various kinds of story books while tiding up the games with the help of several children.

\subsection{Dress-Up Game}

This dress-up game can be interpreted as a make-over leading to a type of social game [26]. The first type of dress-up game, called "Barbie Fashion Designer", was introduced in 1997 and had sold over 600.000 copies in its first year. This kind of game is very successful in attracting children's attention among the ten types of games played most often, both online and offline. There are two types of dress-up game models comprising of (1) doll play and (2) identity play. In doll play, the children play the role of the puppeteer, creating a character which is different from the player himself. In identity play, popular as an avatar or play costume, the player appears as a character in the game wearing clothes for himself.

This dress-up game can be said as a form of children's personal expression, in which children can modify the character's appearance for certain themes. Players can use several clothes and match them according to the desired fashion style. This game may provide children with the opportunity to experiment with different identities, hence, allowing children to play around with different preferences. The findings show that one of the important motives for playing this game model is because the game provides opportunities for children to learn what it is like to be a model [27]. Through this dress-up game, it will be seen how children understand their gender.

Ludiaca stated that the dress-up game is a game to identify gender [28]. In general, this game simulates dress-ups for various character plays. Based on this, it can be concluded that the game of dress up is a game of self-identification or gender through costumes that are matched according to the character and theme being played.

\subsection{Characteristics of 3-4 Years Old Children}

Children aged 3-4 years are in early childhood education, especially playgroups. The characteristics of children at that time can be described as follows: (a) at the age of 3-4 years, the children are in the pre-operational stage. In the preoperational phase, children's thinking patterns are symbolic, children like to play with objects and imagine with those objects. Children also absorb their activities and satisfy themselves, can add, subtract and change things according to the knowledge they have. This operation allows him to solve problems logically according to the children's point of view [29]. (b) Children are unique, they possess uniqueness as in learning styles, interests, and family backgrounds. The uniqueness of each child is followed by the innate, interests, abilities and cultural backgrounds and lives which are different from each other. Although there are general sequence patterns in children development which can be predicted, the patterns of development and learning have differences from each other [30]. (c) Children have imagination and fantasy, they have their world, different from people above their age. Interested in things which are imaginative so they are rich in fantasy. Sometimes, they ask something that cannot be guessed by adults. It is due to having an extraordinary fantasy and developing beyond what they see. To enrich children's imagination and fantasy, experiences need to be provided to stimulate their ability to develop [31]. Moreover, (d) children have a short concentration range.

Generally, children find it difficult to concentrate on an activity for a long period. They always quickly turn their attention to other activities, except those activities, besides being fun, they are also varied and not boring. The concentration range of children aged 3-4 years is, generally, ten minutes to sit and pay attention to something comfortably. a short attention makes them very difficult to sit and pay attention to something for a long period, except for things which are interesting and pleasing to him. 
Learning can be conducted by using a variety of fun approaches, so as not to keep children stuck on the spot and listening for a long time [32]. Dress-up game does not require a long time to play because this game only pairs the attributes into the picture of male and female figures. Thus, dress-up games are suitable to be played by children aged 3-4 years.

\section{Method}

The method used was action research. Action research, in principle, is intended to develop skills or to solve a problem in the classroom [33]. It was confirmed by McNiff that the main basis of this method is to enhance professional services of educators in handling the teaching and learning process by taking various alternative actions in solving the learning problems. In this case, the researcher or teacher conduct something in which the direction and objective of the research are clear, which is in the interest of students in obtaining satisfactory learning outcomes. In action research, there are two activities administered simultaneously, which are action activities (action) and research activities (research) [34]. Both of these activities can be conducted by the same person or different people who work together collaboratively.

The action intervention design/cycle of this study used the Kemmis and Taggart models. The working procedures in action research according to Kemmis and Taggart in Arikunto include the following stages: (a) planning, (b) acting, (c) observing, (d) reflecting, then proceed with replanning, actions, observations, and reflexes for the next cycle, and so on to form a spiral.

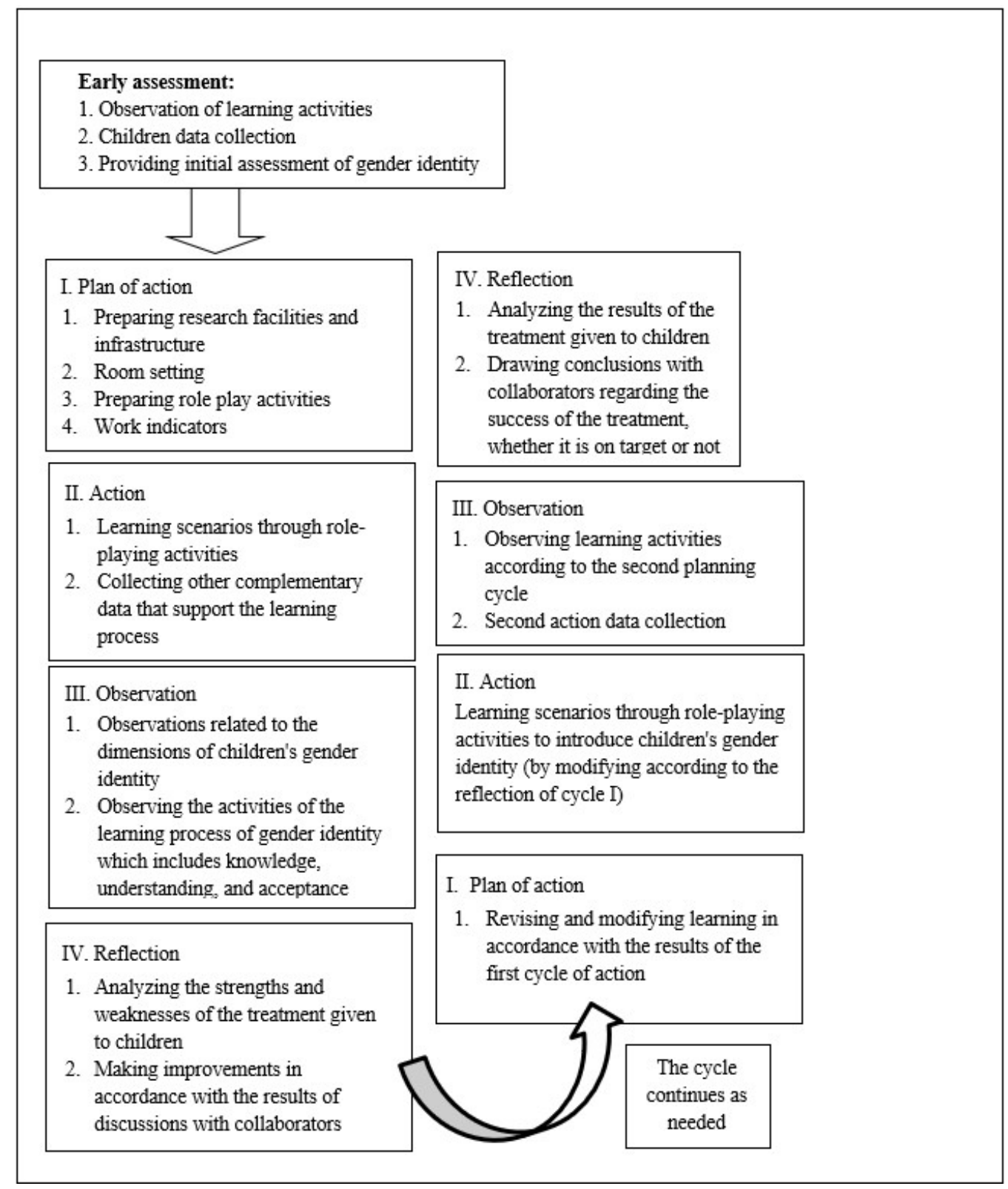

Figure 1. Research Planning Design 


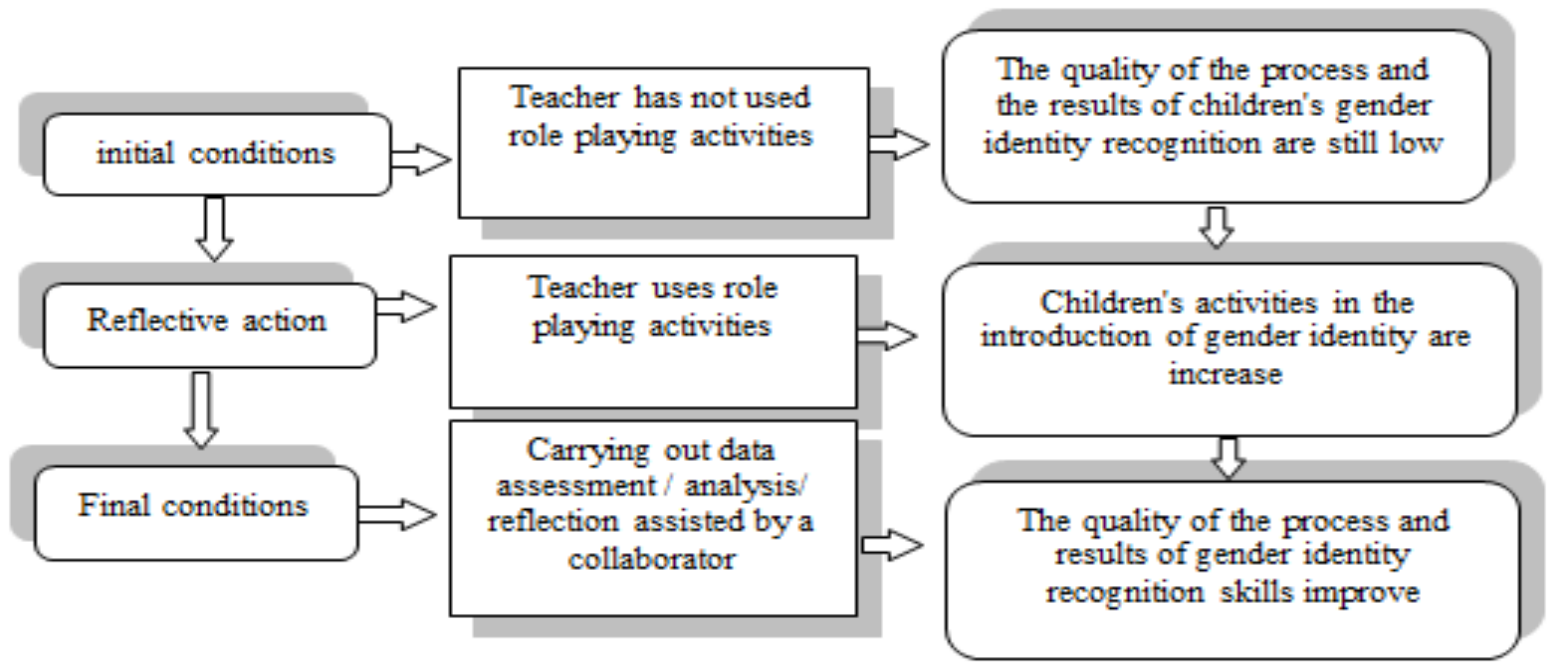

Figure 2. Conceptual Framework

This study analyzed ways to increase the gender identity of children aged 3-4 years through role-playing activities in KB Al-Ikhlas, Bekasi. Data sources in this study were children aged 3-5 years at KB Al-Ikhlas, Bekasi, who were the primary data sources totaling 15 people, principals who provided information about learning activities at school, and collaborators involved in research were the classroom teacher named Ms. Hj. Tati Nurhayati, S. Pd. The framework of thinking in this study is visualized in the picture above.

\section{Results and Findings}

The research data was described in the form of quantitative and qualitative data presentation. Quantitative data was used to see the percentage increase in each cycle. Meanwhile, qualitative data to analyze data obtained through field notes, interview notes, and documentation notes in the field. The following is a description of quantitative data regarding the introduction of children gender identity through role-playing activities.

Before the researchers conducted the first cycle, the researchers administered pre-research preparations, which was searching for and collecting preliminary data on the children's gender identity examined through direct observation and discussion with classroom teachers. Based on the results of observations of children's gender identity in pre-research, it showed that children do not know and understand their gender identity optimally. When the researcher made observations, there were no indicators provided rise to knowledge of gender identity in children such as, knowledge, understanding, and acceptance of themselves as a male and female. It can be identified when introducing the theme of themselves, the children only know the name, gender and place of residence. However, they do not yet understand the roles which have to be performed as men and women. In the teaching and learning process, teachers tend to be the center of learning, while children only listen to the material. There was even a child who was playing alone in the corner when the teacher explained the lesson. These conditions were responded by the teacher by scolding and punishing the children.

According to the monitoring of researchers when conducting observations, several factors caused children not understand their gender identity which consist of the first factor, there is a target of achievement for all children to be able to read, write and count, thus, the material about their themes is used as material for children to learn to write; the second factor is the teacher's monotony in using learning methods; the third factor is the use of media that is less varied, so learning is often delivered abstractly or only in the form of speech without any tangible evidence of what is explained by the teacher; and the fourth factor is teachers tend to be the center of learning while students only listen to the material. The lecture and question-and-answer method are still often used when delivering material so that children quickly feel bored. The following is a visualization of pre-cycle data, cycle 1 to cycle 2 introductions to gender identity in children aged 3-4 years at KB Al-Ikhlas. 
Table 1. Data on increasing children's gender identity

\begin{tabular}{|c|c|c|c|c|c|c|}
\hline \multirow[t]{2}{*}{ Respondent } & \multicolumn{3}{|c|}{ Percentage } & \multirow{2}{*}{$\begin{array}{c}\begin{array}{c}\text { Percentage } \\
\text { Increase }\end{array} \\
\text { Cycle } 1\end{array}$} & \multirow{2}{*}{$\begin{array}{c}\begin{array}{c}\text { Percentage } \\
\text { Increase }\end{array} \\
\text { Cycle } 2\end{array}$} & \multirow{2}{*}{$\begin{array}{c}\text { Total Percentage } \\
\text { Increase }\end{array}$} \\
\hline & Pre-Cycle & Cycle 1 & Cycle 2 & & & \\
\hline 1 & $35.6 \%$ & $57.2 \%$ & $89.2 \%$ & $21.6 \%$ & $32 \%$ & $53.6 \%$ \\
\hline 2 & $26.8 \%$ & $50.5 \%$ & $82.3 \%$ & $23.7 \%$ & $31.8 \%$ & $55.5 \%$ \\
\hline 3 & $28.7 \%$ & $52.1 \%$ & $75.3 \%$ & $23.4 \%$ & $23.2 \%$ & $46.6 \%$ \\
\hline 4 & $30 \%$ & $54.6 \%$ & $87.5 \%$ & $24.6 \%$ & $32.9 \%$ & $57.5 \%$ \\
\hline 5 & $27.5 \%$ & $47.8 \%$ & $82.7 \%$ & $20.3 \%$ & $34.9 \%$ & $55.2 \%$ \\
\hline 6 & $28.7 \%$ & $50.5 \%$ & $83.2 \%$ & $21.8 \%$ & $32.7 \%$ & $54.5 \%$ \\
\hline 7 & $30 \%$ & $51.6 \%$ & $84.5 \%$ & $21.6 \%$ & $32.9 \%$ & $54.5 \%$ \\
\hline 8 & $28.7 \%$ & $49.2 \%$ & $81.2 \%$ & $20.5 \%$ & $32 \%$ & $52.5 \%$ \\
\hline 9 & $31.8 \%$ & $55 \%$ & $86.8 \%$ & $23.2 \%$ & $31.8 \%$ & $55 \%$ \\
\hline 10 & $30 \%$ & $51.3 \%$ & $80.1 \%$ & $21.3 \%$ & $28.8 \%$ & $50.1 \%$ \\
\hline 11 & $27.5 \%$ & $48.7 \%$ & $78.5 \%$ & $21.2 \%$ & $29.8 \%$ & $51 \%$ \\
\hline 12 & $28.7 \%$ & $51.5 \%$ & $82.5 \%$ & $22.8 \%$ & $31 \%$ & $53.8 \%$ \\
\hline 13 & $25 \%$ & $44.1 \%$ & $73.8 \%$ & $19.1 \%$ & $29.7 \%$ & $48.8 \%$ \\
\hline 14 & $28.7 \%$ & $52.5 \%$ & $83.7 \%$ & $23.8 \%$ & $31.2 \%$ & $55 \%$ \\
\hline 15 & $27.5 \%$ & $45.3 \%$ & $75.1 \%$ & $17.8 \%$ & $29.8 \%$ & $47.6 \%$ \\
\hline Average & $29.1 \%$ & $50.7 \%$ & $81.8 \%$ & $21.6 \%$ & $31.1 \%$ & $52.7 \%$ \\
\hline
\end{tabular}

The following is a visualization graph of increasing the gender identity of children aged 3-4 years through role-playing activities:

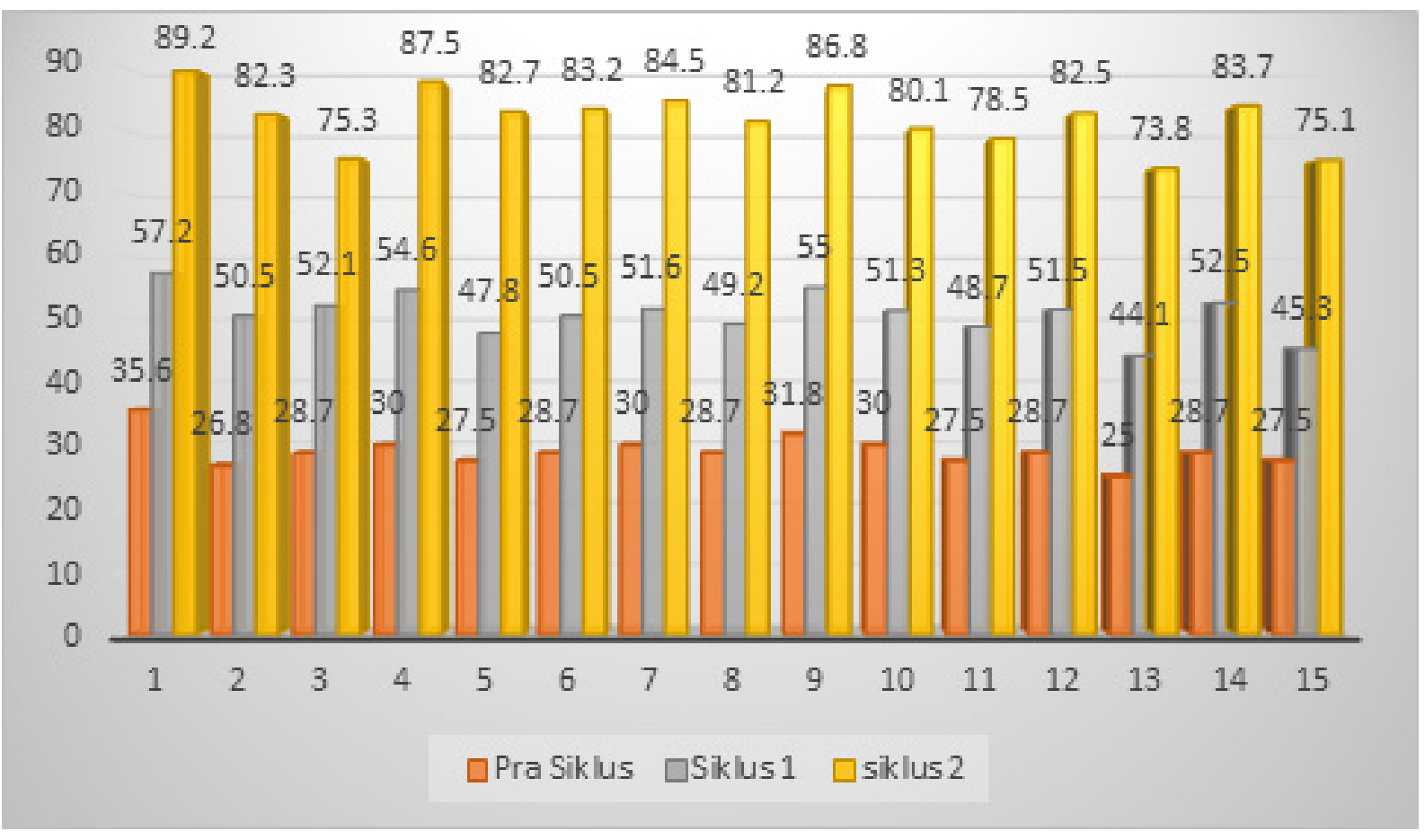

Figure 2. Gender Identity Graph 
Based on the comparison of the gender identities percentage of children aged 3-4 years in pre-cycle with data in cycle 2, there was an increase in the recognition of children's gender identity by $52.7 \%$ after being provided action through play activities. The increase has reached the research target of $71 \%$, and the percentage increase has been observed to be significant due to the continuous increase. Based on the results of data analysis in cycle 1 , the percentage increase was $21.6 \%$ and in cycle 2 , the percentage increase was $31.1 \%$. Thus, the percentage increase entirely from pre-cycle to cycle 2 of $52.7 \%$. It means that there has been a significant increase in the percentage of children's gender identity recognition in pre-study cycle 2 .

The role-playing activities to improve gender identity in playgroup children can be seen in the table below:

Table 2. Action Cycle 1 and 2

\begin{tabular}{|c|c|c|c|}
\hline No. & Themes & Activity Description & Tools \\
\hline 1. & My school & $\begin{array}{l}\text { Children play micro roles } \\
\text { in school settings and } \\
\text { match types of school } \\
\text { clothing for boys and girls. }\end{array}$ & $\begin{array}{l}\text { Set of school } \\
\text { clothes and } \\
\text { accessories } \\
\text { for boys and } \\
\text { girls }\end{array}$ \\
\hline 2. & $\begin{array}{l}\text { Worship } \\
\text { place }\end{array}$ & $\begin{array}{l}\text { Children play micro roles } \\
\text { with the setting of places } \\
\text { of worship and matching } \\
\text { types of clothing for } \\
\text { worshiping for boys and } \\
\text { girls. }\end{array}$ & $\begin{array}{c}\text { Set of } \\
\text { worship } \\
\text { clothes and } \\
\text { accessories } \\
\text { for boys and } \\
\text { girls } \\
\end{array}$ \\
\hline 3. & Playground & $\begin{array}{l}\text { Children play micro roles } \\
\text { by setting a playground } \\
\text { and matching types of play } \\
\text { clothes for boys and girls. }\end{array}$ & $\begin{array}{c}\text { Set of play } \\
\text { clothes and } \\
\text { accessories } \\
\text { for boys and } \\
\text { girls } \\
\end{array}$ \\
\hline 4. & $\begin{array}{c}\text { Birthday } \\
\text { party }\end{array}$ & $\begin{array}{l}\text { Kids play micro roles with } \\
\text { birthday party settings and } \\
\text { match types of party } \\
\text { clothes for boys and girls. }\end{array}$ & $\begin{array}{l}\text { Set of party } \\
\text { wear and } \\
\text { accessories } \\
\text { for boys and } \\
\text { girls }\end{array}$ \\
\hline
\end{tabular}

The results of qualitative data analysis prove that role-playing activities can improve the understanding of children's gender identity. The process of recognizing gender identity through role-playing activities applied by children shows an increase. It can be seen from the observation of actions showing that the teacher has conducted all learning activities following the learning scenarios that have been made. Meanwhile, the implementation of learning undertaken by children also increased. In the end of the first cycle meeting, it was seen that the increase in children's gender identity reached $50.7 \%$ and increased at the end of the second cycle to $81.8 \%$.

The principles of learning in role-playing activities had been implemented well by both teachers and children. The suitability of role-playing activities in introducing gender identity to children was based on the objective of the method and the condition of the learner. The teacher has also taken steps to play roles perfectly. These methods created the enthusiasm and attention of children, and make them possess an interest in conducting learning activities which have an impact on increasing children's gender identity. It is consistent with McDougall, Strong, Crow and Crow's statement which stated that a person is interested if he or she has hidden attention and motivation that encourages giving attention to someone or an activity.

Role-playing activities can also build children's knowledge background, clarify abstract words, and build meaning in learning. Early childhood in understanding an explanation or an event occurring cannot only be in verbal form when the teacher or parent explains. However, children need a play activity which can help children to form a new understanding. Direct experience provided for children will affect the effectiveness of the learning process because it can be enjoyed by children visually.

One focus achieved by conducting role-playing activity is children may have knowledge, understanding, and acceptance of their gender identity. One strategy to achieve this focus is to implement role-playing activities in recognizing children's gender identity. Learning activities can increase the children's enthusiasm and interest in learning. In the pre-cycle, children tend to be passive, unfocused, chatting with friends, and do the other activities because the teacher only utilized books to explain gender identity. However, during the process of identifying one's own gender identity, the teacher stimulated role-playing activities that make children become very active, enthusiastic, and have high attention when the implementation of the action took place. It is because role-playing activities are tremendously fun for children. The learning experienced by children becomes more meaningful and can lead to an interest in children. Therefore, role-playing activities are very important in the learning process. It follows the characteristics of early childhood learning in which children learn through play.

\section{Conclusions}

This research shows that role-playing activities can introduce gender identity to children. Several things can be concluded from this research which are:

- The learning process conducted with role playing activities, especially playing micro roles with dress-up media, has a good influence in introducing gender identity to children.

- $\quad$ Role-playing activities, especially playing micro roles with dress-up media, can improve gender identity in children including knowledge, understanding, and acceptance.

- Role-playing activities were conducted with four themes, which are "my school, a place of worship, a playground, and a birthday party."

- The increase score related to sexual identity in children at pre-study was $29.1 \%$. After being implemented the action in the first cycle, the score increased to $50.7 \%$. Then, after being administered 
the action in cycle II, the score increased to $81.8 \%$. Based on the results of these percentages, the results show that role-playing activities can make children understand their gender identity including knowledge, understanding, and acceptance of themselves as a man or woman.

\section{REFERENCES}

[1] R. I. Arends, Learning to Teach, 9 th ed. McGraw-Hill Companies, Inc, 2012.

[2] J. W. Santrock, Child Development Fourteenth Edition. New York: Mc Graw Hill Education, 2011.

[3] A. E. Roig and M. J. R. Hurtado, "The digital gap: gender and computer games," vol. 9, no. November, 2010.

[4] D. Nielsen, "Identity Performance in Roleplaying Games," Comput. Compos., vol. 38, no. December, pp. 45-56, 2015.

[5] A. Wolfook, Educational Psychology Fourteenth Edition (14th ed.). 2019.

[6] D. F. Morrow, Sexual Orientation and Gender Expression in Social Work Practice. Columbia: University Press, 2006.

[7] J. W. Santrok, Psikologi Perkembangan. Jakarta: Kencana, 2015.

[8] G. B. Soaraka, Sociology: Cultural Diversity in a Changing World. London: Allyn dan Bacon, 1997.

[9] B. Newman, Development Through Life: A Psychological Approach. London: Cengage Learning, 2014.

[10] Sandfort, H. B. Children's Identity in Lesbian and Heterosexual Two Parents Family. Springer, 2010.

[11] P. A. Raburu, "The Self-Who Am I? Children's Identity and Development Through Early Childhood Development," $J$. Educ. Soc. Res., pp. 95-100, 2015.

[12] P. A. Clark, "Learning Gender in Primary School Playgrounds: Finding From the Tomboy Identities Study," $J$. Paedagog. Cult. Socienty, pp. 317-331, 2007.

[13] On, N. C. Healthy Gender Development and Young Children. Early Childhood National Center, 2018.

[14] McCaslin, N. Creative Dramatics in the Classroom. McKay, 2009.

[15] Smilansky, S., \& Shefatya, L. Facilitating Play: A Medium for Promoting Cognitive, Socio- Emotional and Academic Development in Young Children. Psychosocial and Educational Publications, 2002.

[16] McCaslin, N. Creative Dramatics in the Classroom. McKay, 2009.
[17] C. H. Wolfgang, B. Mackender, and M. E. Wolfgang, Growing and learning through play. Instructo, 2009.

[18] Shaftel, F. R., \& Shaftel, G. A. Role-playing for social values. Prentice-Hall, 2008.

[19] Pakdaman-savoji, A., \& Nesbit, J. C. The conceptualisation of cognitive tools in learning and teachnology: A review. Australasian Journal of Educational Technology, 35(2), pp. $1-24,2019$.

[20] Bowman, S. L., \& Lieberoth, A. Psychology and Role-Playing Games. In Role-Playing Game Studies, 2019.

[21] Haenilah, Y. E. Kurikulum dan Pembelajaran PAUD. Media Akademi, 2019.

[22] Madyawati, L. Strategi Pengembangan Bahasa Pada Anak. Prenadamedia Group, 2016.

[23] Nirwana. Penerapan Metode Bermain Peran Makro terhadap Kemampuan Bicara. Jurnal Intruksional, 1(66), pp. 9-16, 2019.

[24] Rumilasari, N. P. D., Tegeh, I. M., \& Ujiati, P. R. Pengaruh Metode Bermain Peran (Role Playing) Terhadap Kemampuan Berbicara pada Anak Kelompok A. E-Journal Pendidikan Anak Usia Dini Universitas Pendidikan Ganesha, 4(2), pp. 1-11, 2016.

[25] Nurani, Y. Konsep Dasar PAUD. Indeks, 2010.

[26] Surayya, N., \& Setyabudi, D. The Significance of Playing Dress-up games on Children's Materialism. The European Journal of Social and Behavioural Sciences, 16(2), pp. 2101-2115, 2016

[27] Ryan, R. Glued to games: how video games draw us in and hold us spellbound. In Praeger (Vol. 49, Issue 01). Praeger, 2019 .

[28] Ludica, Fron, J., Fullerton, T., Morie, J. F., \& Pearce, C. Playing Dress-Up: Costumes, roleplay and imagination. Philosophy of Computer Games, 2007.

[29] Strickland, B. R. The Gale Encyclopedia of Psychology. In Simply Psychology, Second Edition. Gale Group, 2014.

[30] Elicker, J., \& Benson, M. Developmentally appropriate. Young Children, 2013

[31] Y. Nurani, Konsep Dasar Pendidikan Anak Usia Dini. Jakarta: Indeks, 2012

[32] Brown, C. P., \& Lan, Y. C. The influence of developmentally appropriate practice on children's cognitive development: A qualitative metasynthesis. Teachers College Record, pp. 115(12), 2013.

[33] M. Handini, Metodologi Penelitian Untuk Pemula. Jakarta: FIP Press, 2012

[34] S. Arikunto, Penelitian Tindakan Kelas. Jakarta: Bumi Aksara, 2015. 